\title{
Accidental Carbon Monoxide Poisonings in Adana, Turkey: A 14-year Study
}

\author{
Adana'da Taksirle Meydana Gelen Karbon Monoksit Zehirlenmeleri: 14 Yıl Çalışması
}

\author{
Murat Darçın \\ Ministry of Interior Affairs, Gendarmerie and Coast Guard Academy, Ankara, Turkey
}

Abstract

\begin{abstract}
Aim: Carbon monoxide (CO) is often referred to as the "silent killer" because its victims cannot see it, smell it or taste it. CO is responsible for a large percentage of the accidental poisonings and deaths reported throughout the world. CO poisoning therefore is considered a serious global health threat. The aim of the present study was to describe the cases of CO poisoning in a rural areas of Adana, Turkey between 2002 and 2015 based on data collected from incident reports
\end{abstract}

Methods: The cases of accidental CO poisoning were statistically analyzed. During that period, 74 incidents occurred and 154 people were poisoned by accidental CO poisoning.

Results: The results of this analysis indicate that men and adults aged $\geq 65$ years were more likely to die from CO poisoning than others. The number of $\mathrm{CO}$ poisoning cases was highest during the heating season. The majority (72\%) of poisoning resulting in hospitalization with a life-threatening condition or death occurred within the home.

Conclusion: CO poisoning is a serious danger. People must be informed about this hazard. By educating risk groups about the dangers of CO poisoning, it is possible to save many lives as well as reduce the health risks.

Keywords: Accident, carbon monoxide poisoning, health and safety, public health

\section{Introduction}

Carbon monoxide (CO) is a colorless, odorless, tasteless, nonirritating, invisible and poisonous gas, which is predominantly produced as a result of incomplete combustion of carbon-containing materials, such as gas, coal, coke, wood, etc. CO is often referred to as the "silent killer" because its victims cannot see it, smell it or taste
Öz

Amaç: Karbon monoksit (CO), kurbanları onu göremediği, koklayamadığı ve tadamadığı için genellikle sessiz katil olarak anılır. CO zehirlenmeleri dünya çapında rapor edilen taksirle zehirlenme sonucu ölümlerin önemli bir yüzdesinden sorumludur. Bu yüzden CO zehirlenmesi küresel ölçekte ciddi bir sağlık tehdidini karakterize eder. Bu çalışmanın amacı, 2002-2015 arasındaki dönemde meydana gelen CO zehirlenmelerini, Adana ili şehir merkezi dışı alanlarda vuku bulan CO zehirlenmesi olgularına ilişkin olay raporlarından toplanan verilere dayanarak ortaya koymaktır.

Yöntemler: Çalışmada, taksirle CO zehirlenmeleri istatistiksel olarak incelenmiştir. Dönem boyunca gerçekleşen 74 olayda 154 kişi kazayla $\mathrm{CO}$ maruziyeti sonucu zehirlenmiştir.

Bulgular: Bu analizin sonuçları, erkeklerin ve 65 yaş üstü yetişkinlerin diğerlerine oranla CO zehirlenmesi sonucu ölme olasılığının daha yüksek olduğunu ortaya koymuştur. CO zehirlenme olgularının sayısı ısıtma sezonunda en yüksek seviyededir. Ölüm veya hayati tehlike kaydı ile hastaneye yatışla sonuçlanan zehirlenme olgularının büyük bir kısmı (\%72) evde gerçekleşmiştir.

Sonuç: CO zehirlenmesi ciddi bir tehlikedir. Insanlar bu tehlike hakkında bilgilendirilmek zorundadır. Risk gruplarını CO zehirlenmesinin tehlikeleri konusunda eğiterek, sağlık risklerini azaltmakla birlikte birçok hayat kurtarmak da mümkündür

Anahtar Sözcükler: Kaza, karbon monoksit zehirlenmesi, sağlık ve güvenlik, halk sağlığı

it. Exposure to higher concentrations of $\mathrm{CO}$ can result in death (1).

The exact number of individuals who have suffered from CO intoxication is not known because of unreported incidents. As one of the most common cause of poisoning in the developed and developing countries alike $(2,3)$, $\mathrm{CO}$ poisoning is responsible for a large percentage of
Address for Correspondence/Yazışma Adresi: Murat Darçın

Ministry of Interior Affairs, Gendarmerie and Coast Guard Academy, Ankara, Turkey

Phone: +90 5057511516 E-mail: mrtdrc@yahoo.com

Received/Geliş Tarihi: 01 March 2016 Accepted/Kabul Tarihi: 03 July 2016
${ }^{\circ}$ Copyright 2017 by The Medical Bulletin of Haseki Training and Research Hospital The Medical Bulletin of Haseki published by Galenos Yayınevi. ๑Telif Hakkı 2017 Haseki Eğitim ve Araştırma Hastanesi Haseki Tıp Bülteni, Galenos Yayınevi tarafından basılmışır. 
the accidental poisoning deaths reported throughout the world. CO poisoning, which may be the cause of more than $50 \%$ of the fatal poisonings reported in many countries $(4,5)$, has also been determined to be the leading cause of death of accidental poisoning in Europe (6). CO poisoning therefore is a serious health threat on a global level. Most of poisoning deaths caused by accidental CO poisoning can be prevented with simple prevention measures (7).

CO poisoning from coal and gas heaters is one of the major public health problems in Turkey, and the number of studies on CO poisoning is limited. The aim of the present study was to describe CO poisonings between 2002 and 2015 based on data collected from incident reports of CO poisoning cases occurring in rural areas of Adana, Turkey.

\section{Methods}

Accidental CO poisonings in the rural areas of Adana were investigated on the incident reports during the period 2002-2015. Data were analyzed with respect to type, cause, result and time of incident, age and gender of victims, and other factors. Initially, 74 accidental CO poisoning incidents were identified. Data used this study was taken from Gendarmerie accident and incident reports.

The statistics program XLSTAT was used for the descriptive and analytical evaluation of the parameters of the $\mathrm{CO}$ poisoning incidents. Association rules were used as the statistical method to find the relationship between data items in a transactional database. As an important branch of data mining techniques, association rules mining aims to find the associations between features in large dataset. $A$ rule describes the association between two sets ( $X$ and $Y$ ) that have no collective elements. $X \Rightarrow Y$ means, if we have $X$ in a process; in this case, we can have $Y$ in the same process. Support of a rule is the possibility of finding sets $X$ and $Y$ in a process. How frequently the items in a rule occur together is indicated as the support of a rule. This value ranges from 0 to 1 . In association rule analysis, the confidence of a rule is defined as follows: Confidence $(X \Rightarrow Y)=$ support $(X \cup Y) /$ support $(X)$. The confidence is how often a rule has been encountered in the data, The lift of a rule is the ratio of the observed support to that expected if $X$ and $Y$ were independent. A lift value greater than 1 indicates a positive relationship between the itemsets; lift value less than 1 indicates a negative link; and where the value of lift equals 1, the correlation is independent and there is no association between the itemsets (8).

\section{Results}

During the 14-year period, 1844 people were poisoned in 1292 poisoning cases. Victims were poisoned because of products used for human health $(27.8 \%$; $n=512)$, foods (22.6\%; $\mathrm{n}=416)$, agricultural pesticides and animal health products $(21 \% ; n=388), C O(8.4 \% ; n=154)$, plants and wild mushrooms (7.2\%; $n=33)$, household chemicals $(4.4 \% ; n=82)$, industrial chemicals $(1.8 \% ; n=34)$, animals $(1 \% ; n=18)$, and other reasons (5.8\%; $n=107)$ (Figure 1).

During the period, 74 incidents were occurred and 154 people were intoxicated due to accidental $\mathrm{CO}$ poisoning. 13 CO-poisoned victims died, 16 people were hospitalized with a life-threatening condition, and 125 people were hospitalized without a life-threatening condition.

$79 \%$ of poisoned people who were hospitalized with a life-threatening condition or dead were male. The rate of severe poisoning resulting in hospitalization with a life-threatening condition or death was highest among elderly. More than $50 \%$ died victims were over 65 years of age (Figure 2). The results of this analysis indicate that men and adults aged $\geq 65$ years were more likely to die from CO poisoning than other persons. $15 \%$ of fatal CO poisoning and more than one-third of total $\mathrm{CO}$ poisoning occurred among those younger than 18 years of age (Figure 2,3).

The number of $\mathrm{CO}$ poisoning cases was highest during the heating season. $\mathrm{CO}$ poisoning was most common in winter. The period November through February represent the leading months for $\mathrm{CO}$ poisoning resulting in hospitalization with a life-threatening condition or death in rural areas of Adana, with a peak in December (Figure 4). A large number of fatal CO poisoning (85\%) also occurred during the winter months.

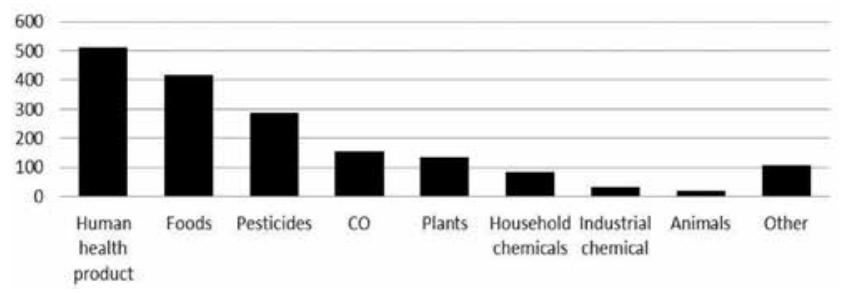

Figure 1. Poisoned victims during the fourteen-year period

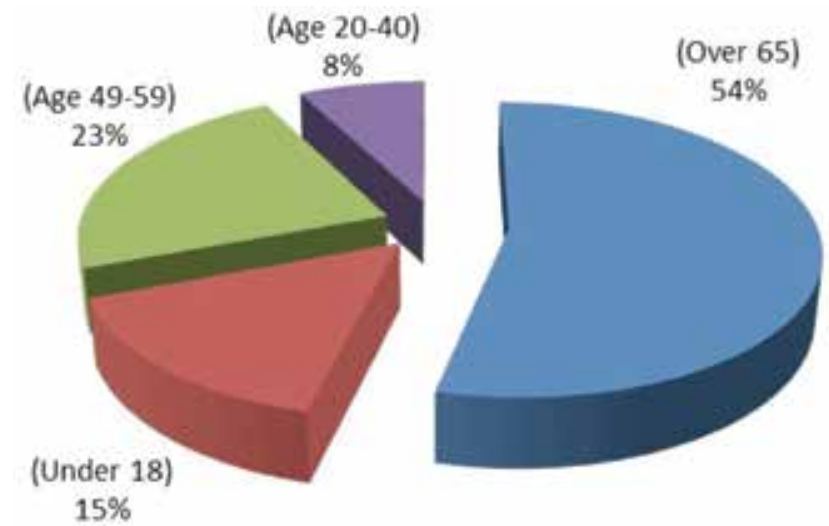

Figure 2. Died victims due to carbon monoxide poisoning 
The majority (72\%) of poisonings resulting in hospitalization with a life-threatening condition or death occurred within the home (Figure 5). Another finding of this study is that $21 \%$ of poisonings resulting in hospitalization with a life-threatening condition or death occurred within a tent which is used by agriculture workers (Figure 5). Nearly one-third (31\%) of all CO deaths occurred inside tents.

During the period, any criminal investigation about co-related suicide was not conducted and no case was

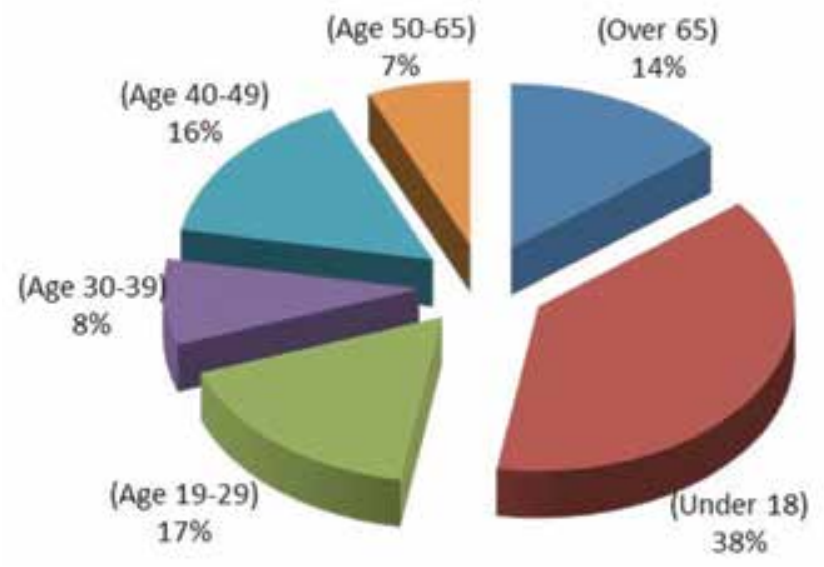

Figure 3. Fatal and nonfatal carbon monoxide poisoning due to age

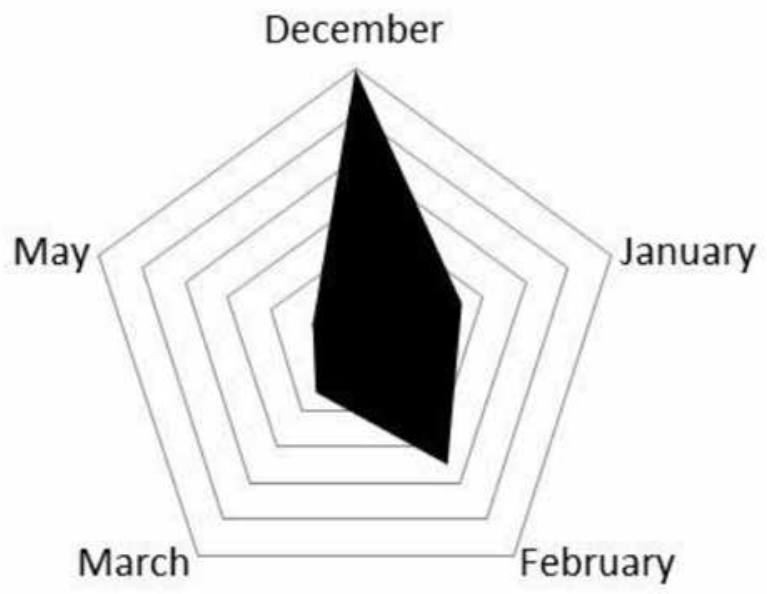

Figure 4. Fatal carbon monoxide poisoning due to months

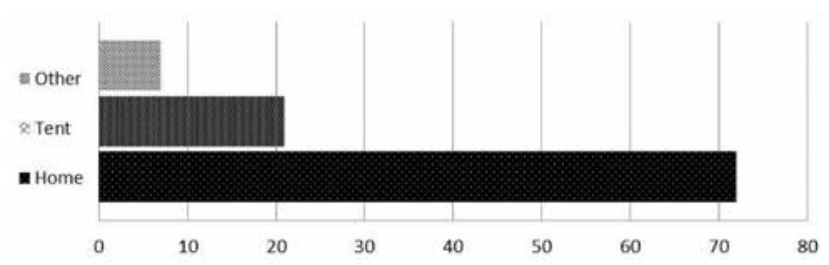

Figure 5. Place of carbon monoxide poisoning resulting in hospitalization with a life-threatening condition or death recorded as suicide in this study. Another important result of the study is that $69 \%$ of fatal CO poisoning victims were alone while poisoning has occurred.

The summary of association rules analysis is shown in Table 1 (minimum support: 0.06; minimum confidence: 0.95; minimum number antecedent: 4; items: 28 ; rules: 13 ).

One of the rules with the highest confidence says that if a female under the age 18 is exposed to non-fatal $\mathrm{CO}$ poisoning at home, then there is $100 \%$ chance that she is also not alone in the home. This rule is found in $12.2 \%$ of the transactions. The lift is 1.103 which means that having ( $<18$ - female - Home - non-fatal poisoning) or respectively (Not-Alone) increases the chance of having (Not-Alone) or respectively ( $<18$ - female - Home - non-fatal poisoning) by a factor of 1.103. The same rule also applies to men.

Another rule says that if a male age 30-39 is not alone at a workplace, then there is $100 \%$ chance that he is also exposed to non-fatal CO poisoning. This rule is found in $6.4 \%$ of the transactions. The lift is 1.255 which means that having (30-39 - male - Not-Alone - Workplace) or respectively (Non-Fatal poisoning) increases the chance of having (Non-Fatal poisoning) or respectively (30-39 - Male - Not-Alone - Workplace) by a factor of 1.255 . Some of the other rules are displayed in Table 2 (minimum support: 0.05; minimum confidence: 0.95; minimum number antecedent: 2; items: 28; rules: 148).

Rules say that:

-If a person who died from poisoning is alone at the time of poisoning, then there is $100 \%$ chance that the person is a man. This rule is found in $5.2 \%$ of the transactions.

-If a person over age 65 is not alone, then there is $100 \%$ chance that the person is at home. This rule is found in $5.2 \%$ of the transactions.

-If a person is exposed to non-fatal CO poisoning in a tent, then there is $100 \%$ chance that he/she is also not alone in the tent. This rule is found in $12.8 \%$ of the transactions.

If a female is in a tent, then there is $100 \%$ chance that she is also not alone. This rule is found in $9.3 \%$ of the transactions.

-If a female is exposed to non-fatal CO poisoning in a tent, then there is $100 \%$ chance that she is also not alone in the tent. This rule is found in $8.7 \%$ of the transactions.

\section{Discussion}

Characteristics of the at-risk population for severe and fatal CO poisoning in this study is largely consistent with previous studies that both male and elderly population subgroups have the highest rates of CO-related hospitalization and death (4,9-12). Although all people need to be aware of the $\mathrm{CO}$ poisoning threats, vulnerable 
populations such as unborn babies, infants, elderly, and those who suffer from anemia, heart disease or respiratory problems are generally more at risk than others (13).

Most CO exposures and poisonings occur when people are in the home $(7,12,14)$. Especially in the winter months, leaks from coal heaters are the major instruments of deaths $(15,16)$. Data from Bursa, Turkey for the period between 1996 and 2006 showed that coal heater emissions were the source in $86 \%$ of $\mathrm{CO}$ poisoning cases (7). The present study found that $92 \%$ of fatal CO poisonings were

\begin{tabular}{|l|l|l|l|l|}
\hline Table 1. Summary of association rules (minimum number antecedent: 4) & Consequence & Confidence & Support & \multicolumn{1}{|l|}{ Lift } \\
\hline Antecedent & Not-Alone & 1.000 & 0.122 & 1.103 \\
\hline$<18$ - Female - Home - Non-Fatal poisoning & Non-Fatal poisoning & 0.955 & 0.122 & 1.198 \\
\hline$<18$ - Female - Home - Not-Alone & Not-Alone & 1.000 & 0.122 & 1.103 \\
\hline$<18$ - Home - Male - Non-Fatal poisoning & Not-Alone & 1.000 & 0.093 & 1.103 \\
\hline Female - Home - Jan - Non-Fatal poisoning & Not-Alone & 1.000 & 0.076 & 1.103 \\
\hline$<18$ - Home - Jan - Non-Fatal poisoning & Non-Fatal poisoning & 1.000 & 0.076 & 1.255 \\
\hline$<18$ - Home - Jan - Not-Alone & Home & 1.000 & 0.076 & 1.445 \\
\hline Dec - Male - Not-Alone - Non-Fatal poisoning & Not-Alone & 1.000 & 0.076 & 1.103 \\
\hline Dec - Home - Male - Non-Fatal poisoning & Not-Alone & 1.000 & 0.070 & 1.103 \\
\hline$<18$ - Female - Jan - Non-Fatal poisoning & Non-Fatal poisoning & 1.000 & 0.070 & 1.255 \\
\hline$<18$ - Female - Jan - Not-Alone & Male & 1.000 & 0.064 & 1.849 \\
\hline $30-39-$ Not-Alone - Non-Fatal poisoning - Workplace & Not-Alone & 1.000 & 0,064 & 1.103 \\
\hline $30-39-$ Male - Non-Fatal poisoning - Workplace & Non-Fatal poisoning & 1.000 & 0.064 & 1.255 \\
\hline $30-39-$ Male - Not-Alone - Workplace & & & \\
\hline Dec: December, Jan: January & & & \\
\hline
\end{tabular}

\begin{tabular}{|c|c|c|c|c|}
\hline Antecedent & Consequence & Confidence & Support & Lift \\
\hline Not-Alone - Workplace & Male - Non-Fatal poisoning & 1.000 & 0.110 & 2.646 \\
\hline 30-39 - Workplace & Male - Non-Fatal poisoning & 1.000 & 0.064 & 2.646 \\
\hline 30-39 - Not-Alone - Workplace & Male - Non-Fatal poisoning & 1.000 & 0.064 & 2.646 \\
\hline 30-39 - Workplace & Male - Not-Alone - Non-Fatal poisoning & 1.000 & 0.064 & 2.646 \\
\hline Non-Fatal poisoning - Workplace & Male - Not-Alone & 1.000 & 0.110 & 2.098 \\
\hline 30-39 - Workplace & Male - Not-Alone & 1.000 & 0.064 & 2.098 \\
\hline 30-39 - Non-Fatal poisoning - Workplace & Male - Not-Alone & 1.000 & 0.064 & 2.098 \\
\hline Not-Alone - Workplace & Male & 1.000 & 0.110 & 1.849 \\
\hline Not-Alone - Non-Fatal poisoning - Workplace & Male & 1.000 & 0.110 & 1.849 \\
\hline Alone - Fatal poisoning & Male & 1.000 & 0.052 & 1.849 \\
\hline$>65$ - Not-Alone & Home & 1.000 & 0.099 & 1.445 \\
\hline DEC - Male - Not-Alone - Non-Fatal poisoning & Home & 1.000 & 0.076 & 1.445 \\
\hline$>65$ - Female & Home & 1.000 & 0.052 & 1.445 \\
\hline$>65$ - Non-Fatal poisoning & Home & 1.000 & 0.052 & 1.445 \\
\hline$>65$ - Male - Not-Alone & Home & 1.000 & 0.052 & 1.445 \\
\hline 30-39 - Male - Workplace & Not-Alone - Non-Fatal poisoning & 1.000 & 0.064 & 1.293 \\
\hline$<18$ - Female - Home & Not-Alone - Non-Fatal poisoning & 0.955 & 0.122 & 1.234 \\
\hline Non-Fatal poisoning - Tent & Not-Alone & 1.000 & 0.128 & 1,103 \\
\hline Female - Tent & Not-Alone & 1.000 & 0.093 & 1.103 \\
\hline Female - Non-Fatal poisoning - Tent & Not-Alone & 1.000 & 0.087 & 1.103 \\
\hline \multicolumn{5}{|l|}{ Dec: December } \\
\hline
\end{tabular}


caused by wood or coal heaters. This result also supports previous research. A study from the USA found that the most common sources of $\mathrm{CO}$ poisoning in homes were the use of gasoline-powered engines, such as electric generators, and malfunctioning heating and cooking appliances (17). Incorrectly installed, poorly maintained or poorly ventilated cooking and heating devices are often the foremost causes of $\mathrm{CO}$ poisoning.

CO alarms are an important part of a whole strategy for the prevention of $\mathrm{CO}$ poisoning and deaths. Of all the $\mathrm{CO}$ incidents recorded in this study, none of those involving an alarm resulted in a fatality or serious injury. Similar to this study, it has been found that households do not have a working CO alarm (12). Different from other countries, $\mathrm{CO}$ is rarely used as a suicide method in Turkey.

\section{Conclusion}

CO poisoning is common, severe and ignored incident throughout the world, with a relatively high risk of immediate death, complications or late health problems. $\mathrm{CO}$ poisoning is a mostly avoidable and preventable public health problem that usually occur by accidents. Public awareness and education is vital for protection from poisoning. It is important to avoid dangerous $\mathrm{CO}$ concentrations exposures in homes and other indoor environments. CO poisoning can be reduced through measures such as regular checks and maintenance of heating systems, use of monitoring devices/CO alarm detectors for the early detection of excess $\mathrm{CO}$, development of alternative heating systems, adequate ventilation, not using unventilated combustion sources indoors, and improving protective properties against CO leaks in the existing heating system.

$\mathrm{CO}$ poisoning is a serious danger. People must be informed about it. By educating risk groups about the dangers of CO poisoning, it is possible to reduce the health risk as well as save many lives.

\section{Ethics}

Peer-review: Externally peer-reviewed.

\section{References}

1. Ait EL Cadi M, Khabbal $Y$, Idrissi L. Carbon monoxide poisoning in Morocco during 1999-2007. J Forensic Leg Med 2009;16:385-7.

2. Iheagwara KN, Thom SR, Deutschman CS, Levy RJ. Myocardial cytochrome oxidase activity is decreased following carbon monoxide exposure. Biochim Biophys Acta 2007; 1772:1112-6.
3. Gorman D, Drewry A, Huang $Y L$, Sames $C$. The clinical toxicology of carbon monoxide. Toxicology 2003;187:25-38.

4. Cobb N, Etzel R. Unintentional carbon monoxiderelated deaths in the United States, 1979 through 1988. JAMA 1991;266:659-63.

5. Varon J, Marik PE, Fromm RE Jr, Gueler A. Carbon monoxide poisoning: a review for clinicians. J Emerg Med 1999;17:8793.

6. Burette $P$, Vanmeerbeek $M$, Boüüaert C, Giet D. Family practitioner and carbon monoxide poisoning. Rev Med Liege 2006;61:285-90.

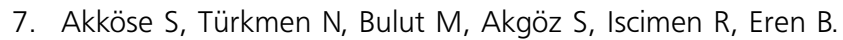
An analysis of carbon monoxide poisoning cases in Bursa, Turkey. East Mediterr Health J 2010;16:101-6.

8. XLSTAT, 2014. https://www.xlstat.com/en/

9. Centers for Disease Control and Prevention (CDC). Unintentional non-fire-related carbon monoxide exposuresUnited States, 2001-2003. MMWR Morb Mortal Wkly Rep 2005;54:36-9.

10. Centers for Disease Control and Prevention (CDC). Carbon monoxide-related deaths-United States, 1999-2004. MMWR Morb Mortal Wkly Rep 2007;56:1309-12.

11. Iqbal S, Law HZ, Clower JH, Yip FY, Elixhauser A. Hospital burden of unintentional carbon monoxide poisoning in the United States, 2007. Am J Emerg Med 2012;30:657-64.

12. Sircar K, Clower J, Shin MK, Bailey C, King M, Yip F. Carbon monoxide poisoning deaths in the United States, 1999 to 2012. Am J Emerg Med 2015;33:1140-5.

13. Centers for Disease Control and Prevention. 2012. What is Carbon Monoxide? Available from: http://www.cdc.gov/co/ pdfs/faqs.pdf. Accessed December 20, 2015.

14. Iqbal S, Clower JH, Hernandez SA, Damon SA, Yip FY. A review of disaster-related carbon monoxide poisoning: surveillance, epidemiology, and opportunities for prevention. Am J Public Health 2012;102:1957-63.

15. Aksoy E, Polat O, Inanıc MA. Retrospective analysis of 293 carbon monoxide poisoning cases. Clinical development 1995;8:3545-9.

16. Turkmen N, Akgoz S. Carbon monoxide intoxication related deaths autopsies in Bursa. J Forensic Med 2005;19:20-5.

17. United States Environmental Protection Agency. An Introduction to Indoor Air Quality (IAQ). Carbon Monoxide (CO). Available from: URL:http://www.epa.gov/iaq/co.html. Accessed December 20, 2015. 